\title{
PENGARUH KEMUDAHAN DAN HARGA TERHADAP KEPUTUSAN PEMBELIAN PRODUK PAKAIAN SECARA ONLINE (Studi Kasus Mahasiswa Belanja Online Pada FEBI IAIN Padangsidimpuan)
}

\author{
Hamni Fadlilah Nasution \\ Institut Agama Islam Negeri Padangsidimpuan \\ Jalan T. Rizal Nurdin Km. 4,5 Sihitang, Padangsidimpuan \\ Email : hamnifadlilahnasution@gmail.com
}

\begin{abstract}
Abstrak,
Transaksi jual beli online semakin berkembang, tidak terkecuali di kalangan mahasiswa. Tujuan penelitian adalah untuk mengetahui pengaruh kemudahan dan harga secara parsial dan simultan terhadap keputusan pembelian produk pakaian secara online studi kasus mahasiswa belanja online pada FEBI IAIN Padangsidimpuan. Penelitian ini adalah penelitian kuantitatif. Sampel penelitian sebanyak 40 responden. Analisis data menggunakan analisis regresi linier berganda. Hasil penelitian ini adalah terdapat pengaruh kemudahan terhadap keputusan pembelian produk pakaian secara online studi kasus mahasiswa belanja online pada FEBI IAIN Padangsidimpuan. Tetapi tidak terdapat pengaruh harga terhadap keputusan pembelian produk pakaian secara online studi kasus mahasiswa belanja online pada FEBI IAIN Padangsidimpuan. Terdapat pengaruh kemudahan dan harga secara simultan terhadap keputusan pembelian produk pakaian secara online studi kasus mahasiswa belanja online pada FEBI IAIN Padangsidimpuan.
\end{abstract}

Kata Kunci: Keputusan Pembelian, Kemudahan, Harga

\begin{abstract}
,
Online buying and selling transactions are growing, not least among students. The purpose of the study was to determine the effect of ease and price partially and simultaneously on the purchase decision of clothing products online case study online shopping students at FEBI IAIN Padangsidimpuan. This type of research used in this research is a quantitative approach. Research samples were 40 respondents. Data analysis using descriptive analysis and multiple linear regression analysis. The results of this study are that there is an effect of ease on purchasing decisions of clothing products online case studies of online shopping students at FEBI IAIN Padangsidimpuan. But there is no price effect on the purchase decision of clothing products online in case studies of online shopping students at FEBI IAIN Padangsidimpuan. There is a simultaneous effect of ease and price on purchasing decisions of clothing products online in case studies of online shopping students at FEBI IAIN Padangsidimpuan
\end{abstract}

Keywords: Purchase Decision, Ease, Price 


\section{PENDAHULUAN}

Teknologi yang terus berkembang memungkinkan terjadinya transaksi jual beli secara online. Menurut penelitian yang dilakukan We Are Social, perusahaan media asal Inggris yang bekerja sama dengan Hootsuite, rata-rata orang Indonesia menghabiskan tiga jam 23 menit sehari untuk mengakses media sosial. Dari laporan berjudul "Essential Insights Into Internet, Social Media, Mobile, and E-Commerce Use Around The World" yang diterbitkan tanggal 30 Januari 2018, dari total populasi Indonesia sebanyak 265,4 juta jiwa, pengguna aktif media sosialnya mencapai 130 juta dengan penetrasi 49 persen. (Wahyuanda, 2018). Internet tak bisa dipisahkan dari kehidupan sehari-hari anak muda zaman sekarang. Sebanyak 49,52 persen pengguna internet di Tanah Air adalah mereka yang berusia 19 hingga 34 tahun (Kompas, 2018). Sehingga ketergantungan akan internet memberikan peluang bagi usaha yang dilakukan secara online yang sering disebut online shop

Berdasarkan data yang ada pada situs Alexa.com (2016), berikut adalah 5 situs jual beli online yang paling banyak dikunjungi di Indonesia. Pada peringkat 9 ditempati oleh Tokopedia.com. Pada peringkat 10 ditempati oleh Bukalapak.com. Pada peringkat 11 ditempati oleh Kaskus.co.id. Pada peringkat 21 ditempati oleh Elevenia.co.id, dan pada peringkat ke 22 ditempati oleh Lazada.co.id.

Online shop menjadi salah satu bentuk pemasaran interaktif yang telah menjadi tren berbelanja di kalangan mahasiswa saat ini. Mahasiswa saat ini sering memanfaatkan media sosial sebagai sarana dalam berbelanja pakaian. Hal ini merupakan salah satu faktor pendorong penggunaan media sosial pada mahasiswa Fakultas Ekonomi dan Bisnis Islam untuk melakukan pembelian produk pakaian secara online.

Tanpa disadari, munculnya perkembangan E-Commerce ini telah merubah gaya hidup dan perilaku. Dahulu, konsumen harus pergi ke tempat untu mendaptkan prosuk yang diinginkannya. Sekarang cukup melalui Online apa yang diinginkan bisa diperoleh. Demikian juga pilihan kemudahan yang diberikan, tergantung keinginan konsumen. Disamping pilihan kemudahan yang ditawarkan produsen, konsumen dapat memilih harga yang diberikan. Harga yang ditampilkan produsen juga beragam, sehingga judul dalam penelitian ini adalah Pengaruh Kemudahan dan Harga Terhadap Keputusan Pembelian Produk Pakaian Secara Online (Studi Kasus Mahasiswa Belanja Online Pada FEBI IAIN Padangsidimpuan).

Berdasarkan permasalahan diatas, keputusan pembelian secara online pada mahasiswa FEBI IAIN Padangsidimpuan erat kaitannya dengan kemudahan yang diperoleh dan harga yang ditawarkan beragam, sehingga konsumen bebas menentukan pilihannya. Tujuan penelitian ini adalah untuk mengetahui pengaruh kemudahan dan harga secara parsial 
dan simultan terhadap keputusan pembelian produk pakaian secara online studi kasus mahasiswa belanja online pada FEBI IAIN Padangsidimpuan.

\section{TINJAUAN TEORITIK}

\section{Keputusan Pembelian}

Pembelian ditentukan oleh konsumen setelah melakukan beberapa tahapan. Tahapantahapan yang dilalui inilah yang akan menimbulkan keputusan untuk melakukan pembelian atau tidak. Keputusan pembelian tentukan akan memunculkan dua atau lebih alternatif pilihan, artinya bahwa seseorang dapat membuat keputusan, harus tersedia beberapa alternatif pilihan( Schiffman dan Kanuk, 2004). Keputusan konsumen memegang peran penting bagi keberlangsungan usaha produsen. Banyak perusahaan yang meneliti keputusan membeli konsumen secara amat rinci untuk menyatakan apa produk yang lagi diminati konsumen, bagaimana konsumen membeli, berapa banyak yang dibeli dan mengapa konsumen membeli produk tersebut. Salah satu cara yang tepat untuk mengetahui hal tersebut adalah dengan faktor-faktor yang mempengaruhi pembelian. Menurut (Kotler dan Keller, 2007), faktor-faktor yang mempengaruhi tingkah laku konsumen itu sendiri adalah 1) Faktor Budaya, yaitu meliputi budaya (penentu keinginan dan perilaku yang mendasar), sub-budaya (bangsa, agama, suku, daerah), dan kelas sosial. 2)Faktor Sosial dalam faktor ini, perilaku seorang konsumen dipengaruhi faktor-faktor sosial seperti kelompok acuan, keluarga, peran dan status. 3)Faktor Pribadi, merupakan faktor pribadi (usia, tahap siklus hidup, pekerjaan, keadaan ekonomi, gaya hidup, kepribadian dan konsep-diri pembeli).

(Kotler dan Keller, 2007) mengemukakan bahwa terdapat lima tahap yang dilalui konsumen dalam proses pengambilan keputusan pembelian. Kelima tahapan tersebut yaitu pengenalan masalah, pencarian informasi,evaluasi alternatif, keputusan pembelian, dan perilaku pasca pembelian. Tahap pertama yaitu pengenalan kebutuhan (Need Recognition). Pada proses ini pembelian dimulai ketika pembeli mengenali masalah atau kebutuhan. Kebutuhan tersebut dapat dicetuskan oleh rangsangan internal atau eksternal. Tahap kedua yaitu pencarian informasi. Seorang konsumen yang terangsang secara internal maupun ekternal akan terdorong untuk mencari informasi yang lebih banyak. Situasi pencarian informasi ada yang hanya sekedar lebih peka terhadap informasi produk. Ada juga konsumen mulai aktif untuk mencari informasi melalui mencari bahan bacaan, browsing di internet, menelepon temannya, mengunjungi toko untuk mengetahui detail mengenai produk yang diinginkannya. Dalam hal ini sering konsumen melihat kemudahan untuk memperoleh produk terlebih dahulu. Disamping harga produk tersebut.

Evaluasi Alternatif adalah tahap yang ketiga. Pada tahap ini tidak ada proses evaluasi tunggal sederhana yang digunakan oleh semua konsumen atau oleh satu konsumen dalam 
semua situasi pembelian. Terdapat beberapa proses evaluasi keputusan, dan model-model terbaru yang memandang proses evaluasi konsumen sebagai proses yang berorientasi kognitif. Pada tahap ini konsumen dianggap membentuk penilaian atas produk dengan sangat sadar dan rasional. Kemudahan memperoleh produk juga menjadi pertimbangan konsumen. Harga produk juga menjadi pertimbangan bagi konsumen untuk mendapatkan produk.

Tahap yang keempat adalah keputusan pembelian. Dalam tahap evaluasi, konsumen membentuk preferensi merek produk yang ada dalam kumpulan pilihan mereka. Konsumen juga dapat membentuk niat untuk membeli merek yang paling disukai. Dalam melaksanakan maksud pembelian, konsumen bisa mengambil lima sub keputusam yaitu merek (merek produk apa yang akan dipilih) tentuk setelah mempertimbangkan kebutuhan dan harga produk, dealer (penyalur), kuantitas (berapa banyak produk yang akan dibeli), waktu (kapan akan melakukan pembelian), dan metode pembayaran (keputusan tentang cara dan prosedur pembelian) secara online atau langsung data ke toko.

Tahap terakhir adalah perilaku pasca pembelian. Distributor atau pemasar masih memiliki tugas setelah pembelian produk terjadi, konsumen akan mengalami suatu tingkat kepuasan atau ketidakpuasan. Kepuasan atau ketidakpuasan konsumen terhadap produk akan mempengaruhi tingkah laku konsumen berikutnya. Konsumen yang merasa puas akan memperlihatkan peluang membeli lagi pada kesempatan dan cenderung mengatakan sesuatu yang serba baik tentang produk yang telah digunakan bahkan cenderung merekomendasikan kepada orang lain. Sebaliknya jika konsumen dalam melakukan pembelian merasa ketidakpuasan dengan produk yang telah dibelinya, maka konsumen akan merubah sikapnya terhadap produk tersebut menjadi sikap yang negatif, bahkan mungkin tidak akan melakukan pembelian ulang terhadap produk tersebut.

Keputusan membeli suatu produk, menurut Swastha (Ambarani, 2013) memiliki struktur sebanyak 7 komponen, antara lain keputusan tentang jenis produk, bentuk produk, tentang merek, tentang penjualnya, tentang jumlah produk, waktu pembelian dan cara pembayaran (Swastha, 1996). Dimensi keputusan pembelian menurut (Kotler dan Amstrong, 2008), sehingga indikator untuk keputusan pembelian adalah:

1. Pemilihan produk/jasa, Pemilihan produk atau jasa adalah alasan mengapa konsumen memilih produk/jasa untuk memenuhi kebutuhan. Sewaktu konsumen melakukan pemilihan produk/ jasa yang beraneka ragam tidak terlepas dari kebutuhan. Pilihan yang beraneka ragam tentu membuka peluang untuk mempertimbangkan harga yang bersaing dari pihak produsen.

2. Pemilihan merek, Pemilihan merek yaitu bagaimana suatu merek memposisikan dirinya di dalam bentuk konsumen yang meliputi citra (image) merek yang unik dari sebuah produk/jasa. Harga dari setiap merek yang tersedia tentu dipertimbangan pihak konsumen. 
3. Pemilihan waktu, Waktu adalah salah satu unsur terpenting bagi konsumen untuk membeli suatu produk/jasa. Kebutuhan akan produk juga didukung oleh kemudahan untuk mendapatkan produk tersebut.

4. Pilihan metode/cara pembayaran, Konsumen harus mengambil pilihan tentang metode/cara pembayaran produk yang dibeli. Kemajuan teknologi juga memberikan kemudahan bagi konsumen untuk membeli barang salah satunya adalah adanya belanja online.

Dalam agama Islam segala kehidupan ada aturan yang menjadi pedeoman. Setiap orang dalam hal ini pelaku ekonomi dianjurkan untuk melakukan perbuatan yang baik dan menghindari perbuatan yang buruk. Begitupula dalam mengambil keputusan pelaku ekonomi harus benar-benar memperhitungkan keputusan yang akan kita ambil. Berikut ini ayat yang di dalamnya terkandung unsur dalam pengambilan keputusan. Menurut pandangan Islam mengenai pengambilan keputusan tersebut berdasarkan QS. Al-Maidah ayat 100 yaitu:

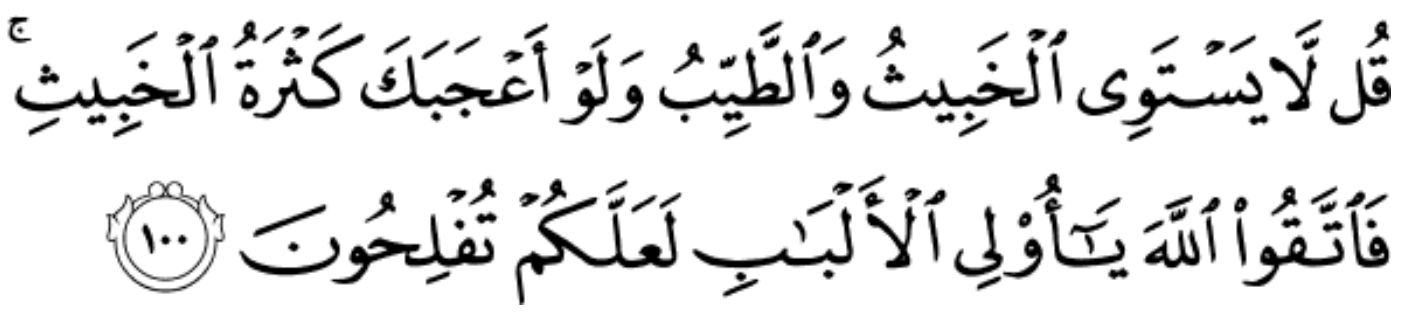

Artinya : Katakanlah: "Tidak sama yang buruk dengan yang baik, meskipun banyaknya yang buruk itu menarik hatimu, maka bertakwalah kepada Allah hai orang-orang berakal, agar kamu mendapat keberuntungan."

\section{Kemudahan}

Jika biasanya konsumen harus mengunjungi toko untuk membeli suatu produk misalnya pakaian. Keberadaan menu transaksi online membuat proses pembelian barang dan jasa dapat dilakukan dengan lebih mudah dan praktis. Pilihan pembayaran yang beragam juga tersedia untuk membantu Anda memenuhi kebutuhan.

Kemajuan teknologi juga menyebabkan semakin banyaknya toko online. Hal ini semakin mempermudah konsumen memperoleh barang. Penyediaan produk juga semakin variatif dan harga bersaing. Tidak lagi khawatir dengan lokasi tempat tinggal yang tidak memungkinkan untuk membeli suatu barang yang sangat diinginkan. Sehingga, Menurut (Jogiyanto, 2007) Kemudahan merupakan ukuran kepercayaan konsumen terhadap teknologi yang menurutnya akan bebas dari usaha. Faktor kemudahaan ini terkait dengan bagaimana operasional bertransaksi secara online. Menurut Park dan Yoon, Internet shopping 
memungkinkan pelanggan untuk menghemat waktu dan usaha mereka saat membeli produk yang diinginkan (Ardyanto, Susilo dan Riyadi , 2015).

\section{Harga}

Harga adalah satuan dari sejumlah uang yang ditukarkan untuk memperoleh manfaat dari suatu produk atau jasa. Harga dalam penelitian ini adalah harga pakaian dalam belanja online. Terdapat tiga indikator harga (Kotler dan Armstrong, 2008), diantaranya : 1). Kelayakan harga, Produk yang dibeli dari online memiliki harga yang pantas menurut konsumen. 2) Kesesuaian harga dengan kualitas produk, Harga produk yang dibeli dari online sesuai dengan kualitas pakaian yang dijual. 3) Adanya diskon / potongan harga, Pembeli dapat mendapatkan diskon / potongan harga apabila pembeli membeli dengan jumlah tertentu.

\section{Kerangka Pikir}

Kemudahan dan harga dalam membeli pakaian secara online adalah faktor yang menjadi suatu pertimbangan dalam membeli suatu produk, hal ini karena sebelum produk tersebut dibeli oleh pelanggan, produsen maupun perusahaan harus mampu menciptakan kemudahan dan harga yang sesuai kepada konsumen terhadap pakaian yang ditawarkan melalui online karena ini bertujuan untuk menarik perhatian serta menimbulkan keputusan pembelian terhadap. Maka disusunlah kerangka pikir penelitian sebagai berikut:

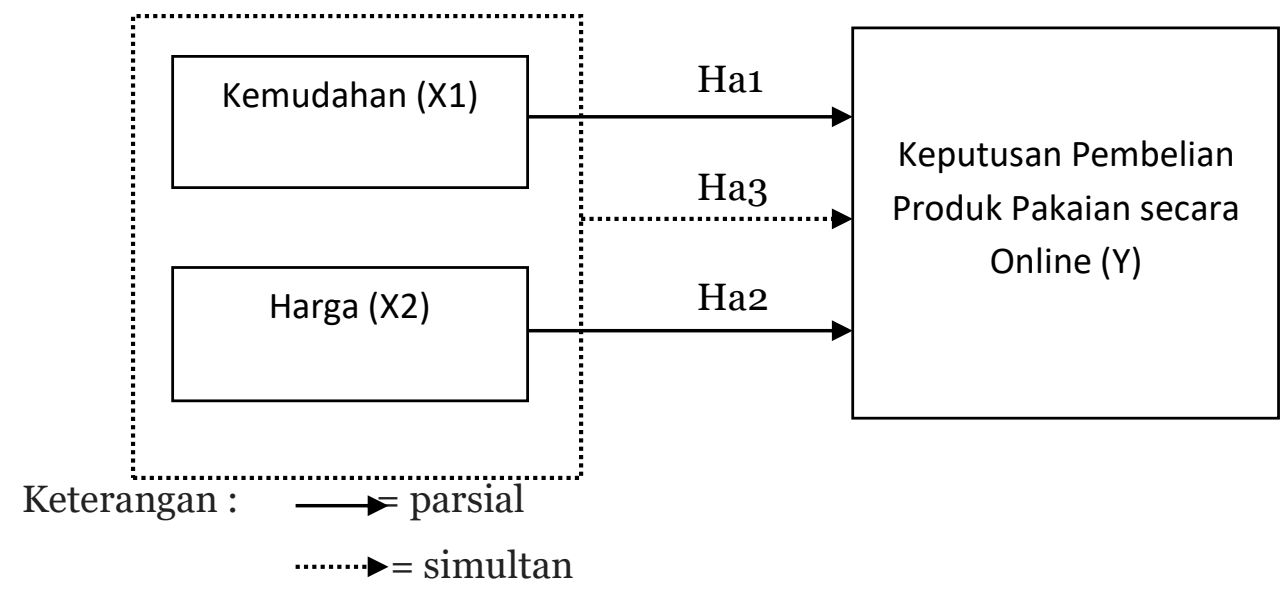

Ha1 = Terdapat pengaruh kemudahan terhadap keputusan pembelian produk pakaian secara online studi kasus mahasiswa belanja online pada FEBI IAIN Padangsidimpuan

Ha2 = Terdapat pengaruh harga terhadap keputusan pembelian produk pakaian secara online studi kasus mahasiswa belanja online pada FEBI IAIN Padangsidimpuan

Ha3 = Terdapat pengaruh kemudahan dan harga secara simultan terhadap keputusan pembelian produk pakaian secara online 


\section{METODE PENELITIAN}

\section{Lokasi Penelitian}

Penelitian ini dilakukan di Fakultas Ekonomi dan Bisnis Islam, Institut Agama Islam Negeri Padangsidimpuan Jalan T. Rizal Nurdin Km. 4,5 Sihitang, Padangsidimpuan 22733 Telepon (o634) 22080 Faximile (o634) 24022.

\section{Jenis Penelitian}

Jenis penelitian yang dilakukan ini adalah penelitian kuantitatif. Penelitian kuantitatif merupakan penelitian yang mempunyai data yang diukur dalam skala numerik (angka) (Kuncoro, 2009). Dalam pendekatan kuantitatif hubungan antara variabel-variabel dianalisis dengan menggunakan teori yang objektif (Sujarweni, 2015).

\section{Populasi dan Sampel Penelitian}

Populasi penelitian ini adalah seluruh mahasiswa Fakultas Ekonomi dan Bisnis Islam yang pernah berbelanja online. Sedangkan jumlah sampel sebanyak 40 responden. Jumlah sampel sudah memenuhi kriteria penelitian koresional. Seperti yang dikemukakan oleh (Sekaran, 2006). Secara umum, untuk penelitian korelasional jumlah sampel minimal untuk memperoleh hasil yang baik adalah 30. Teknik sampling yang digunakan adalah teknik insidental.

\section{Sumber Data}

Data primer yaitu data yang diperoleh secara langsung dari responden yang dijadikan sebagai sampel penelitian yang dianggap memiliki kriteria terhadap permasalahan yang sedang diteliti.

Data Sekunder yaitu data-data yang diperoleh langsung dari data-data tertulis yang terdiri dari arsip yang berhubungan dengan penelitian ini.

\section{Teknik Analisis Data}

Untuk menguji hipotesis yang diajukan, maka dilakukan pengujian secara kuantitatif dengan bantuan program SPSS versi 23.0. uji yang dilakukan untuk menganalisis data penelitian adalah

1. Uji Validitas dan Reliabilitas

a. Uji Validitas

Menurut (Sujarweni, 2015) Uji signifikansi dilakukan dengan membandingkan nilai $r$ hitung dengan $r_{\text {tabel }}$ untuk degree offreedom $(\mathrm{df})=\mathrm{n}-2$, dengan $\mathrm{n}$ adalah jumlah sampel. Menurut (Suwarno dan Martadiredja, 2008), Kriteria dalam pengujian validitas adalah :

1) Jika $r_{\text {hitung }}$ negatif maka butir pernyataan tidak valid

2) Jika $r_{\text {hitung }}$ positif $<r_{\text {tabel }}$ maka butir pernyataan tidak valid

3) Jika $r_{\text {hitung }}$ positif $\geq r_{\text {tabel }}$ maka butir pernyataan valid 
b. Uji Reliabilitas

Dasar pengambilan keputusan untuk uji reliabilitas menurut (Asnawi dan Masyuri, 2011) dianggap reliabel jika nilai cronbach's alpha > 0,6

2. Uji Asumsi Dasar

a. Uji Normalitas

Uji normalitas yang dilakukan adalah uji kolmogrov smirnov dengan dasar pengambilan keputusan (Zulfikar, 2016) adalah jika nilai signifikan< 0,05 maka data tidak berdistibusi normal dan sebaliknya.

b. Uji Liniearitas

Data dapat dilakukan uji regresi linier harus memenuhi syarat data bersifat linier. Dasar pengambilan keputusan uji linieritas (Irianto, 2004) menyatakan jika nilai signifikan< 0,05 maka data mempunyai hubungan yang linier dan sebaliknya.

3. Uji Asumsi Klasik

a. Uji Multikolinearitas

Mendeteksi adanya tidaknya terjadi multikolinearitas adalah dengan melihat nilai VIF (Variance Inflaction Factor) dan Tolerance dengan kriteria jika nilai VIF > 10 maka terjadi multkolineritas dan sebaliknya. Sedangkan tuk nilai Tolerance < 0,05 maka terjadi multikolineritas dan sebaliknya (Sujarweni, 2015).

b. Uji Heterokedastisitas

Uji yang digunakan dalam penelitian ini adalah uji korelasi rank spearman dengan kriteria bila signifikan hasil korelasi < 0,05 maka terjadi gejala heterokedastisitas (Asnawi dan Masyuri, 2011).

4. Uji Regresi Linier Berganda

Analisis regresi linier berganda digunakan untuk menemukan persaman penelitian dengan persamaan : $\mathrm{KP}=\mathrm{a}+\mathrm{b}_{1} \mathrm{~K}+\mathrm{b}_{2} \mathrm{H}+\mathrm{e}$. Dengan keterangan:

$\mathrm{KP}=$ Keputusan Pembelian secara Online

$\mathrm{K}=$ kemudahan

$\mathrm{H} \quad=$ Harga

a $\quad=$ konstanta

b1 dan b2 = koefisien regresi linier berganda

e $\quad=$ standar error tern

5. Uji Hipotesis

a. Koefisien determinasi $\left(\mathrm{R}^{2}\right)$ 
Menurut (Kuncoro, 2009), Koefisien determinasi menunjukkan besarnya persentase sumbangan variabel bebas terhadap variabel terikat.

b. Ujit

Uji t dilakukan untuk mengetahui apakah variabel bebas secara parsial berpengaruh terhadap variabel terikat. Kriteria pengujiannya menurut (Firdaus, 2004) adalah :

Jika $-t_{\text {hitung }}<-t_{\text {tabel }}$ atau $t_{\text {hitung }}>t_{\text {tabel }}$ maka Ho ditolak dan Ha diterima

Jika $t_{\text {tabel }} \leq t_{\text {hitung }} \leq t_{\text {tabel }}$ maka Ho diterima dan Ha ditolak

c. Uji F

Menurut (Firdaus, 2004) mengemukakan bahwa keputusan yang diambil dalam pengujian hipotesis secara simultan yaitu :

Jika $\mathrm{F}_{\text {hitung }}>\mathrm{F}_{\text {tabel }}$ maka Ho ditolak dan sebaliknya

\section{HASIL DAN PEMBAHASAN}

Instrumen yang diberikan kepada 40 responden, kemudian diuji validitas dan reliabilitas instrumennya. Seperti pada tabel berikut :

Tabel 1. Hasil uji validitas

\begin{tabular}{|c|c|c|c|c|}
\hline No & Variabel & Nilai r hitung & Nilai r tabel & keterangan \\
\hline 1 & K1 & 0,614 & \multirow{22}{*}{0,304} & Valid \\
\hline 2 & K2 & 0,692 & & Valid \\
\hline 3 & $\mathrm{~K}_{3}$ & 0,723 & & Valid \\
\hline 4 & K4 & 0,131 & & Tidak Valid \\
\hline 5 & $\mathrm{~K}_{5}$ & 0,742 & & Valid \\
\hline 6 & K6 & 0,379 & & Valid \\
\hline 7 & $\mathrm{H} 1$ & 0,614 & & Valid \\
\hline 8 & $\mathrm{H} 2$ & 0,468 & & Valid \\
\hline 9 & $\mathrm{H}_{3}$ & 0,759 & & Valid \\
\hline 10 & $\mathrm{H}_{4}$ & 0,440 & & Valid \\
\hline 11 & $\mathrm{H}_{5}$ & 0,682 & & Valid \\
\hline 12 & H6 & 0,671 & & Valid \\
\hline 13 & KP1 & 0,786 & & Valid \\
\hline 14 & $\mathrm{KP} 2$ & 0,202 & & Tidak Valid \\
\hline 15 & $\mathrm{KP}_{3}$ & 0,456 & & Valid \\
\hline 16 & $\mathrm{KP}_{4}$ & 0,564 & & Valid \\
\hline 17 & $\mathrm{KP}_{5}$ & 0,411 & & Valid \\
\hline 18 & KP6 & 0,616 & & Valid \\
\hline 19 & $\mathrm{KP} 7$ & 0,659 & & Valid \\
\hline 20 & KP8 & 0,673 & & Valid \\
\hline 21 & KP9 & 0,789 & & Valid \\
\hline 22 & KP10 & 0,644 & & Valid \\
\hline
\end{tabular}

Terdapat 2 item pernyataan yang tidak valid. Hanya item pernyataan yang valid yang diuji reliabilitasnya. 


\begin{tabular}{|l|c|c|}
\hline \multicolumn{1}{|c|}{ Variabel } & $\begin{array}{c}\text { Nilai Cronbach } \\
\text { Alpha }\end{array}$ & Keterangan \\
\hline Kemudahan & 0,708 & Reliabel \\
\hline Harga & 0,618 & Reliabel \\
\hline Keputusan Pembelian & 0,785 & Reliabel \\
\hline
\end{tabular}

Hasil penelitian menunjukan bahwa nilai cronbach's alfa memiliki nilai > dari o,6 maka data reliabel dan dapat digunakan dalam penelitian.

\section{Tabel 3. Uji normalitas}

\begin{tabular}{|c|l|c|c|}
\hline No & \multicolumn{1}{|c|}{ Variabel } & Nilai Sign & Keterangan \\
\hline 1 & Kemudahan & 0,200 & Normal \\
\hline 2 & Harga & 0,200 & Normal \\
\hline 3 & Keputusan Pembelian & 0,200 & Normal \\
\hline
\end{tabular}

Berdasarkan pengujian normalitas tersebut, didapatkan nilai asymp.sig variabel kemudahan, harga dan keputusan pembelian, semuanya mempunyai sign > 0,05 maka semua variabel berdistribusi normal.

\section{Tabel 4. Uji linearitas}

\begin{tabular}{|c|l|c|c|}
\hline No & \multicolumn{1}{|c|}{ Variabel } & Sign linearity & Keterangan \\
\hline 1 & Kemudahan ${ }^{*}$ Keputusan Pembelian & 0,000 & Linier \\
\hline 2 & Harga*keputusan pembelian & 0,000 & Linier \\
\hline
\end{tabular}

Berdasarkan pengujian linearitas tersebut, didapatkan nilai linearity.sig variabel kemudahan dan harga terhadap keputusan pembelian, mempunyai sign < o,oo maka terdapat hubungan yang linier antara variabel bebas dan terikat.

Tabel 5. Uji multikolinearitas

\begin{tabular}{|l|c|c|}
\hline \multicolumn{3}{|c|}{ Collinearity Statistic } \\
\hline Variabel & Tollerance & VIF \\
\hline Kemudahan & 0,745 & 1,342 \\
\hline Harga & 0,745 & 1,342 \\
\hline
\end{tabular}

Berdasarkan nilai tolerance $(0,745)$ yang diperoleh $>0,05$ dan nilai VIF $(1,342)<10$. Sehingga tidak terjadi multikolinearitas pada variabel.

Tabel 6. Uji heterokedastisitas

\begin{tabular}{|c|l|c|c|}
\hline No & \multicolumn{1}{|c|}{ Hasil Korelasi } & Sign & Keterangan \\
\hline $\mathbf{1}$ & Kemudahan & 0,943 & Tidak terjadi heterokedastisitas \\
\hline 2 & Harga & 0,774 & Tidak terjadi heterokedastisitas \\
\hline
\end{tabular}

Nilai sign kemudahan $(0,943)$ dan harga $(0,774)$, masing-masing lebih dari o,o5. Maka tidak terjadi gejala heterokestisitas. 


\section{Analisis Regresi Linier Berganda}

Tabel 7. Regresi linier berganda

Coefficients $^{\mathbf{a}}$

\begin{tabular}{|c|c|c|c|c|c|c|}
\hline \multirow{2}{*}{\multicolumn{2}{|c|}{ Model }} & \multicolumn{2}{|c|}{$\begin{array}{c}\text { Unstandardized } \\
\text { Coefficients }\end{array}$} & $\begin{array}{c}\text { Standardized } \\
\text { Coefficients }\end{array}$ & \multirow[t]{2}{*}{$\mathrm{t}$} & \multirow[t]{2}{*}{ Sig. } \\
\hline & & $\mathrm{B}$ & Std. Error & Beta & & \\
\hline \multirow{3}{*}{1} & (Constant) & , 041 & 4,466 & & ,009 & ,993 \\
\hline & K & 846 & 266 & 457 & 3,180 & ,003 \\
\hline & $\mathrm{H}$ & ,574 & ,301 & ,273 & 1,604 & ,065 \\
\hline
\end{tabular}

a. Dependent Variable: KP

Berdasarkan analisis regresi linier berganda diperoleh persamaan $K P=a+b_{1} K+b_{2} H$ + e, sehingga menjadi $\mathrm{KP}=0,041+0,846 \mathrm{~K}+0,574 \mathrm{H}$ dapat diartikan. Nilai konstanta sebesar o,041 satuan. Artinya jika harga dan kemudahan bernilai o maka keputusan pembelian online sebesar 0,041 satuan. Koefisien kemudahan sebesar 0,846 satuan. Artinya jika kemudahan naik satu satuan sedangkan harga dianggap o maka keputusan pembelian online akan meningkat sebesar 0,846 satuan. Koefisien harga sebesar 0,574 satuan. Artinya jika harga naik satu satuan sedangkan kemudahan dianggap o maka keputusan pembelian online akan meningkat sebesar 0,574 satuan. Koefisien bertanda positif menunjukkan terjadi hubungan yang positif antara kemudahan dan harga terhadap keputusan pembelian produk pakaian secara online.

\section{Koefisien Determinasi}

Tabel 8. Koefisien determinasi

\begin{tabular}{|l|r|r|r|r|}
\hline $\begin{array}{l}\text { Mode } \\
l\end{array}$ & R & R Square & $\begin{array}{c}\text { Adjusted R } \\
\text { Square }\end{array}$ & $\begin{array}{r}\text { Std. Error of } \\
\text { the Estimate }\end{array}$ \\
\hline 1 &, $630^{\mathrm{a}}$ &, 397 &, 365 & 1,70089 \\
\hline
\end{tabular}

a. Predictors: (Constant), K,H

b. Dependent Variable: KP

Nilai R Square atau koefisien determinasi (KD) yang menunjukkan seberapa bagus model regresi yang dibentuk oleh interaksi variabel bebas dan variabel terikat. Nilai KD yang diperoleh 0,397 yang dapat ditafsirkan bahwa kemudahan dan harga memiliki pengaruh kontribusi sebesar 39,7\% terhadap variabel keputusan pembelian online dan 60,3\% lainnya dipengaruhi oleh faktor-faktor lain diluar variabel kemudahan dan harga.

Uji t 
Berdasarkan tabel 7. Diperoleh nilai $t_{\text {hitung }}$ untuk variabel kemudahan adalah 3,180. Untuk $t$ tabel diperoleh 1,684. Berarti $t_{\text {hitung }}(3,180)>t_{\text {tabel }}(1,684)$ maka Ho ditolak. Berarti terdapat pengaruh kemudahan terhadap keputusan pembelian produk pakaian secara online studi kasus mahasiswa belanja online pada FEBI IAIN Padangsidimpuan. Hasil ini sejalan dengan penelitian yang dilakukan Sari Wahyuni dkk yang menyatakan kemudahan mempunyai pengaruh terhadap keputusan pembelian di online fashion shop zalora co.id. Penelitian Fransiska juga menyatakan bahwa Kemudahan memiliki pengaruh yang positif dan signifikan terhadap keputusan pembelian secara online di Tokopedia.com. Hal ini menunjukkan bahwa kemudahan berpengaruh terhadap keputusan pembelian secara online.

Nilai $t_{\text {hitung }}$ untuk variabel kemudahan adalah 1,604. Untuk $t$ tabel diperoleh 1,684. Berarti $t_{\text {hitung }}(1,604)>t_{\text {tabel }}(1,684)$ maka Ho diterima. berarti tidak terdapat pengaruh harga terhadap keputusan pembelian produk pakaian secara online studi kasus mahasiswa belanja online pada FEBI IAIN Padangsidimpuan. Penelitian ini sejalan dengan penelitian yang dilakukan oleh Fransiska yang menyatakan Harga tidak berpengaruh terhadap keputusan pembelian secara online di Tokopedia.com. Demikian juga penelitian yang dilakukan oleh murwatiningsih yang menyatakan tidak ada pengaruh harga terhadap keputusan pembelian secara langsung dan signifikan. Penolakan ini dijelaskan bahwa semakin tinggi harga akan mengakibatkan menurunnya keputusan pembelian online konsumen terhadap produk yang ditawarkan Coruscate Unique. Konsumen akan memilih produk yang menawarkan harga lebih rendah sebelum mengambil keputusan pembelian.

\section{Uji F}

Tabel IV.7 Hasil Uji Signifikansi Simultan (Uji F)

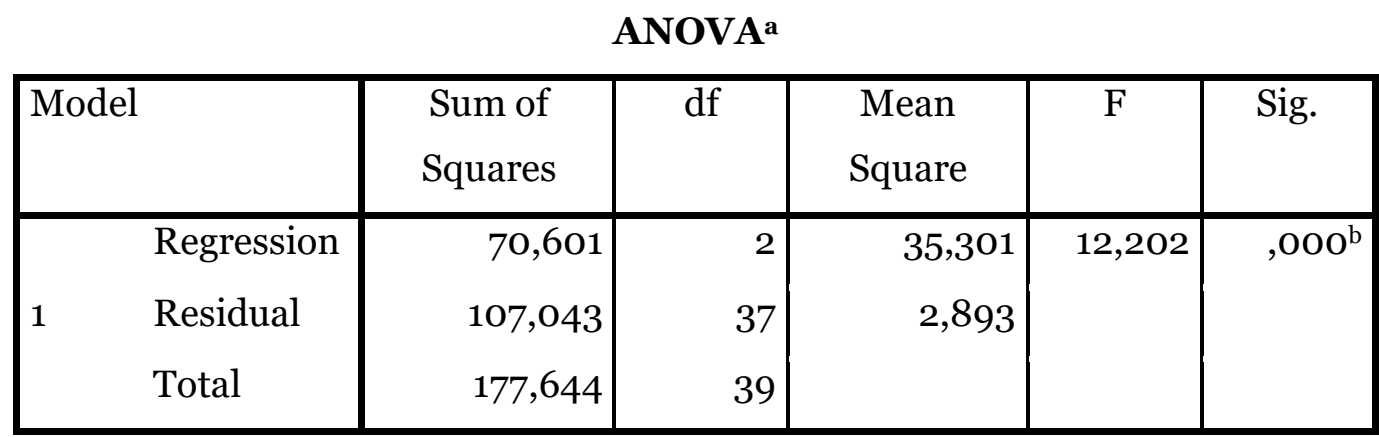

a. Dependent Variable: KP

b. Predictors: (Constant), K, H

Nilai $F_{\text {hitung }}=12,202$ dan $F_{\text {tabel }}=$ 3,252 dengan angka signifikansi sebesar 0,ooo. Pada taraf signifikansi 95\% maka angka signifikansi 0,000 < 0,05 berarti Ho ditolak. Sehingga 
terdapat pengaruh kemudahan dan harga secara simultan terhadap keputusan pembelian produk pakaian secara online.

\section{KESIMPULAN}

Berdasarkan dengan hasil penelitian dan pembahasan yang ada, maka kesimpulan yang dapat ditarik adalah sebagai berikut

1. terdapat pengaruh kemudahan terhadap keputusan pembelian produk pakaian secara online studi kasus mahasiswa belanja online pada FEBI IAIN Padangsidimpuan

2. tidak terdapat pengaruh harga terhadap keputusan pembelian produk pakaian secara online studi kasus mahasiswa belanja online pada FEBI IAIN Padangsidimpuan

3. terdapat pengaruh kemudahan dan harga secara simultan terhadap keputusan pembelian produk pakaian secara online studi kasus mahasiswa belanja online pada FEBI IAIN Padangsidimpuan

\section{DAFTAR PUSTAKA}

Ardyanto, Denni, dan Susilo, Heru, dan Riyadi. 2015. Pengaruh Risiko Dan Harga Terhadap Keputusan Pembelian Melalui Kepercayaan Konsumen Pengaruh Risiko Dan Harga Terhadap Keputusan Pembelian Melalui Kepercayaan Konsumen Pengaruh Kemudahan Dan Kepercayaan Menggunakan E-Commerce Terhadap Keputusan Pembelian Online (Survei Pada Konsumen www.petersaysdenim.com).https://media.neliti.com/media/publications/85897-IDpengaruh-kemudahan-dan-kepercayaan-mengg.pdf

Asnawi, Nur dan Masyuri, 2011. Metodologi Riset Manajemen Pemasaran. Malang : UINMaliki Press

Firdaus, Muhammad, 2004. Ekonometrika Suatu Pendekatan Aplikatif, Jakarta : PT. Bumi Aksara

https://tekno.kompas.com/read/2018/o2/22/16453177/berapa-jumlah-pengguna-internetindonesia.

https://tekno.kompas.com/read/2018/03/o1/10340027/riset-ungkap-pola pemakaianmedsos-orang-indonesia.

Irianto, Agus, 2004. Statistik Konsep Dasar Aplikasi dan Pengembangannya, Jakarta : Kencana

Kamilah, Nisaul, Atik, Hufron, M, dan Slamet, Rachmat, Afi, (2016). Pengaruh Kepercayaan, Kemudahan, Keragaman Produk Dan Gaya Hidup Terhadap Keputusan Pembelian Hijab Merek Hijab Pricess (Studi Kasus Mahasiswa Fakultas Ekonomi Universitas Islam Malang Angkatan 2013-2016 Pengguna Media Sosial Instagram).e - Jurnal Riset Manajemen. Fakultas Ekonomi Unisma. 113-126. riset.unisma.ac.id/index.php/jrm/article/download/440/474 
Kotler, Philip \& Amstrong. 2008. Prinsip-Prinsip Pemasaran. Edisi 12.Jilid 1. Alih Bahasa : Bob Sabran. Jakarta : Erlangga

Kotler, Philip. 2007. Manajemen Pemasaran, edisi ke 12, Jilid 1, Jakarta : PT. Indeks Kelompok Gramedia

Kuncoro, Mudrajad, 2009. Metode Riset untuk Bisnis dan Ekonomi, Jakarta : Erlangga

Murwatiningsih, Erin Puri Apriliani. 2013. Pengaruh risiko dan harga terhadap keputusan pembelian melalui kepercayaan konsumen, jurnal dinamika manjemen JDM Vol 4 No 2, 2013 pp.184-191/ http;//journal.unnes.ac.id/nju/index/php/jdm

Sari Wahyuni, Herry Irawan, M.M., M.T2, Ir. Endang Sofyan, MBT. 2017. Pengaruh Kepercayaan, Kemudahan Dan Kualitas Informasi Terhadap Keputusan Pembelian Online Di Situs Online Fashion Zalora.Co.Id The Influence Of Trust, Easy Of Use And Quality Information On Purchase Decision On Online Fashion Site Zalora.Co.Id. eProceeding of Management : Vol.4, No.2 Agustus 2017 | Page 1405 ISSN : 2355-9357

Sarwono, Jonathan dan Martadiredja, Tutty.2008. Riset Bisnis Untuk Pengambilan Keputusan, Yogyakarta : CV Andi Offset.

Schiffman, Leon G. and Leslie Lazar Kanuk. 2004. Customer Behavior. Prentice Hall Inc, USA. Sekaran, Uma. 2006. Metode Penelitian Bisnis. Jakarta : Salemba Empat.

Sudjatmika, Vania, Fransiska. 2017. Pengaruh Harga, Ulasan Produk, Kemudahan, Dan Keamanan Terhadap Keputusan Pembelian Secara Online Di Tokopedia.Com. Agora Vol. 5, No. 1, https://media.neliti.com/media/publications/54086-ID-pengaruhharga-ulasan-produk-kemudahan-d.pdf

Sujarweni, Wiratna, V. 2015. Metodologi Penelitian: Bisnis dan Ekonomi, Yogyakarta : Pustaka baru press

Swastha, Basu. 1996. Asas-asas Marketing.Yogyakarta : Liberty

Zulfikar, 2016. Pengantar Pasar Modal dengan Pendekatan Statistika, Yogyakarta: Deepublish 